\title{
Improvement of the technology of bakery products using the wholemeal spelt flour
}

\author{
Nadezhda Sanzharovskaya ${ }^{1 *}$, Natalia Sokol $^{1}$, Olga Khrapko $^{1}$, and Kyamran Mamedov ${ }^{1}$ \\ ${ }^{1}$ Kuban State Agrarian University, 13, Kalinina street, Krasnodar, 350044, Russia
}

\begin{abstract}
Bread is one of the most popular mass-consumption products in Russia and in the world. The improvement of the bread quality, the development of new varieties with increased nutritional and biological value will improve the nutrition patterns of the population in the most rational way. The objective of this study is to justify the use of wholemeal spelt flour in the formulation of wheat bread. Generally accepted standard research methods were used. It is experimentally proved that the addition of spelt flour to the flour blend increases the activity of amylolytic enzymes, as well as decreases the mass fraction of crude gluten in all dough samples. When adding the spelt flour in the proportion $40 \%$ of the flour weight, physical and chemical parameters did not deteriorate and fell within the normal range, compared with the control sample of wheat bread. It is proved that the use of spelt flour in the production of bakery products will increase the biological and nutritional value of products, as well as expand the range of products for healthy nutrition.
\end{abstract}

\section{Introduction}

Nowadays, in many countries of Europe and Asia, flour produced from spelt, an ancient grain variety, is actively used in the technology of bread-making [1].

Spelt is the progenitor of all grain varieties. In ancient times, the spelt was one of the most common grain crops in Russia, but since the beginning of the XIX century and until recently, this crop was not cultivated in Russia on an industrial scale and was imported from Europe at very high prices. In recent years, it has been experiencing a revival in Russia due to the necessity for handling the problem of import substitution of food products and due to the biologically valuable features of spelt $[2,3]$.

The use of spelt as a food crop is an interesting and promising trend in the development of the bread baking industry. The biological potential of spelt depends on its varieties and cultivation conditions. The production of spelt grain does not require special climatic and soil conditions. The crop is drought-resistant, produces a heavy crop and is resistant to a number of diseases and pests. Its nutritional value is characterised by a high protein content and a balance of essential amino acids. The content of valine, isoleucine, leucine, methionine + cysteine is close to the ideal protein. The biological value of spelt flour is explained by the predominance of water- and salt-soluble protein fractions and, consequently, a higher degree of digestibility of spelt proteins. Spelt flour is rich in unsaturated fatty acids, vitamins $\mathrm{A}, \mathrm{E}, \mathrm{B}_{1}, \mathrm{~B}_{2}, \mathrm{~B}_{3}$ and has a high level of total and reducing sugars, which are necessary for the activity of Baker's yeast in the production of bakery products. In addition, spelt flour contains special soluble mucopolysaccharides that can boost the human immune system $[4,5]$.

The production volume of spelt grain has increased significantly and keeps growing both in Russia and abroad. Therefore, it is promising to use the speltderived products in the technology and formulation of wheat bread.

The research objective was to justify the use of wholemeal spelt flour in the formulation of wheat bread.

\section{Objects and methods of research}

As the research objects, we used the following:

- all-purpose wheat flour M 75-23;

- wholemeal spelt flour of Runo variety;

- wheat-spelt flour blend in the proportion of 80:20, 60:40; 40:60; 20:80, respectively;

- bakery semi-finished products (sourdough, dough);

- test and control samples of bakery products.

The protein-proteinase complex of the obtained blends was studied by determining the mass fraction and the quality of raw gluten. The autolytic activity was estimated based on the falling number using the Falling Number Device-3, and the physical properties of dough were evaluated using a Farinograph.

The quality of raw materials and finished products was estimated by a combination of organoleptic and physical-and-chemical parameters using standard methods.

The chemical composition of bakery products was determined by the calculation method based on the chemical composition tables of Russian food products, taking into account the loss of nutrient materials and caloric value during the heat treatment of products.

\footnotetext{
* Corresponding author: $\underline{\text { hramova-n@mail.ru }}$
} 
The safety assessment was carried out in accordance with the requirements of the Technical Regulations of the Customs Union 021/2011 "On food safety".

Statistical processing of the results was performed using the Microsoft Office Excel. Replication per treatment is three-time.

\section{Results and discussion}

The quality of wheat flour is usually judged by its baking properties. These properties include the gas-producing power of flour and the flour strength, as well as the granulometric composition, colour and the darkening ability during the bread-making process [6].

Recently, the gas-producing power of flour, which reflects the state of the carbohydrate-amylase complex, has been often replaced by a parameter that characterizes the autolytic activity of flour - the falling number. The falling number is a more operational parameter and can be used for incoming inspection, as well as for regulation of the autolytic activity of semi-finished products in the bread-making process.

To study more thoroughly how the spelt flour affects the baking properties of the wheat flour, we have conducted studies on the estimation of amylolytic activity. The falling number of the gelatinized waterflour suspension of the wheat-spelt flour blend was determined.

Composite flour blends were prepared by subgrading of 20,40,60, 80 and $100 \%$ spelt flour to wheat flour. The samples were mixed in a laboratory rotary mixer. The research results are shown in Figure 1.

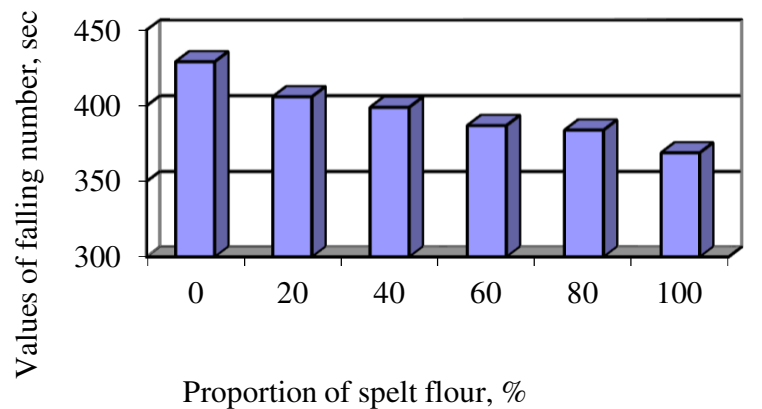

Fig. 1. Value of the falling number in the study samples.

It was found that the activity of amylolytic enzymes increased with an increase in the proportion of spelt flour in the composite blend, which is evidenced by the decrease of the falling number. This can be explained by the high degree of starch saccharification of spelt flour due to the increased activity of amylolytic enzymes (enzymatically active flour).

The flour strength is one of the main parameters of the baking values of wheat flour, which is characterized by the mass fraction of crude gluten and its quality on the Gluten Deformation Meter. The research results of the effect of spelt flour on the mass fraction and the quality of gluten in the blends when added to all-purpose wheat flour are shown in Table 1.
Table 1. The effect of spelt flour on the properties of gluten.

\begin{tabular}{|l|c|c|}
\hline $\begin{array}{c}\text { Percentage content } \\
\text { of spelt flour of the } \\
\text { total weight of } \\
\text { flour }\end{array}$ & $\begin{array}{c}\text { Mass fraction } \\
\text { of crude } \\
\text { gluten, \% }\end{array}$ & $\begin{array}{c}\text { Gluten quality, units } \\
\text { of Gluten } \\
\text { Deformation Meter }\end{array}$ \\
\hline 0.0 & $27.24 \pm 0.12$ & $85.0 \pm 1.2$ \\
\hline 20.0 & $27.10 \pm 0.14$ & $82.5 \pm 0.9$ \\
\hline 40.0 & $26.60 \pm 0.21$ & $81.3 \pm 0.7$ \\
\hline 60.0 & $26.20 \pm 0.18$ & $80.9 \pm 0.6$ \\
\hline 80.0 & $25.84 \pm 0.19$ & $80.0 \pm 0.7$ \\
\hline 100.0 & $25.74 \pm 0.22$ & $78.3 \pm 1.1$ \\
\hline
\end{tabular}

The analysis of the obtained results showed that the increase in the proportion of spelt flour leads to the reduction of mass fraction of gluten and a slight strengthening of the structure of gluten proteins. This is explained by the reduced content of the alcohol-soluble gluten fraction in the protein complex of spelt flour gliadin, which can intensively swell during kneading and fermentation and participate in the formation of an elastic, easily stretchable mass - gluten.

In all study samples, the gluten belonged to II quality group (adequately low) [7, 8].

Since the added component affects the gluten complex of flour, we have studied the structuralmechanical properties of the test samples [9]. To determine the physical properties of dough, a Brabender farinograph was used. The interpretation results of pharynograms are shown in Table 2.

Table 2. The effect of spelt flour on the structural-mechanical properties of dough.

\begin{tabular}{|c|c|c|c|c|c|}
\hline $\begin{array}{c}\text { Propo } \\
\text { rtion } \\
\text { of } \\
\text { spelt } \\
\text { flour, } \\
\%\end{array}$ & $\begin{array}{c}\text { Baking } \\
\text { absorption } \\
\text { of flour, \% }\end{array}$ & $\begin{array}{c}\text { Time of } \\
\text { dough } \\
\text { develop } \\
\text { ment, } \\
\text { min }\end{array}$ & $\begin{array}{c}\text { Dough } \\
\text { resistan } \\
\text { ce, min }\end{array}$ & $\begin{array}{c}\text { Dough } \\
\text { dilution, } \\
\text { farinogr } \\
\text { aph } \\
\text { units }\end{array}$ & $\begin{array}{c}\text { Valorime } \\
\text { tric } \\
\text { estimatio } \\
\text { n, \% }\end{array}$ \\
\hline 0 & 70.9 & 9.0 & 11.0 & 170 & 68 \\
\hline 20 & 71.1 & 11.0 & 10.0 & 160 & 76 \\
\hline 40 & 70.4 & 10.0 & 10.0 & 160 & 74 \\
\hline 60 & 70.7 & 8.0 & 9.0 & 157 & 64 \\
\hline 80 & 70.4 & 7.0 & 8.0 & 155 & 60 \\
\hline 100 & 71.0 & 6.5 & 6.5 & 145 & 58 \\
\hline
\end{tabular}

Following the analysis of the research data of structural-mechanical properties of composite flour blends using the farinograph, it should be noted that substitution of wheat flour with spelt flour does not significantly affect the baking absorption [10].

As follows from the farinogram readings, in case of mechanized kneading, with an increased proportion of added component, the dough develops faster and the time of dough resistance decreases, which can be explained by the reduction of prolamine fraction of proteins and the expansion in the number of watersoluble substances in the liquid phase of dough with the addition of spelt flour [11, 12].

The peculiarities of the structural-mechanical properties of the dough made from a wheat-spelt flour 
blend inevitably affect the biotechnological processes that take place during fermentation, so we have determined such a parameter as the yeast baking strength. The yeast baking strength was determined using the accelerated method by the dough-ball-floating speed (Figure 2).

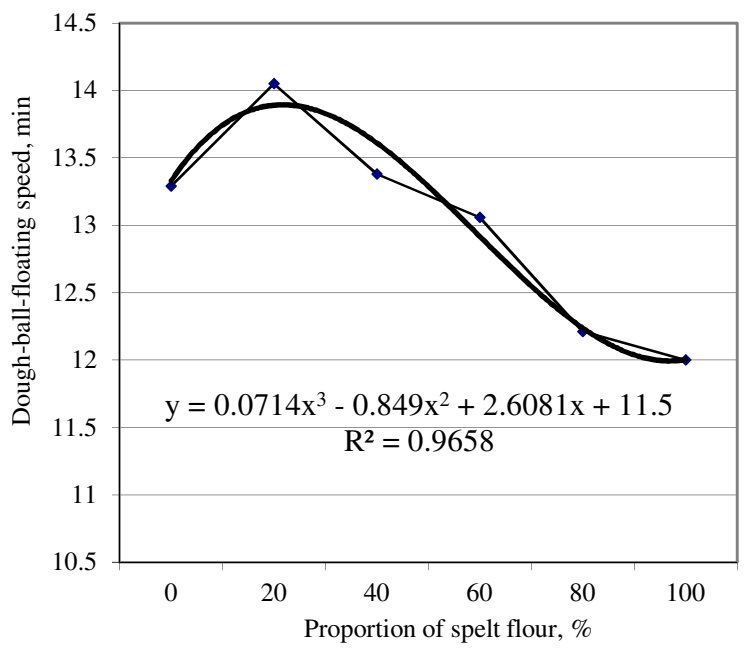

Fig. 2. The effect of spelt flour on the baking strength of compressed yeasts.

The analysis of the obtained results let us to deduce that the most optimal proportions in terms of the dough quality and its manufacturability are $20-40 \%$ spelt flour. However, considering the functional properties of the finished product, we recommend using spelt flour in the proportion of $40 \%$ when preparing the composite blend.

Next, we studied the effect of spelt flour on the acid accumulation during the dough fermentation. The active acidity and the titratable acidity were studied in real-time mode immediately after kneading, as well as 30, 60, 90 and 120 minutes after the fermentation process (Table $3)$.

Table 3. Assessment of the effect of spelt flour on the acid accumulation.

\begin{tabular}{|l|l|l|l|l|}
\hline \multirow{2}{*}{$\begin{array}{l}\text { Fermentation } \\
\text { time, min }\end{array}$} & \multicolumn{2}{|c|}{ Active acidity, pH } & \multicolumn{2}{c|}{ Titratable acidity, ${ }^{\circ} \mathrm{T}$} \\
\cline { 2 - 5 } & Control & $\begin{array}{c}40 \% \\
\text { spelt } \\
\text { flour }\end{array}$ & Control & $\begin{array}{c}40 \% \\
\text { spelt } \\
\text { flour }\end{array}$ \\
\hline 0 & 6.63 & 6.55 & 1.1 & 1.6 \\
\hline 30 & 6.52 & 6.31 & 1.4 & 2.2 \\
\hline 60 & 6.03 & 5.98 & 1.6 & 2.4 \\
\hline 90 & 5.98 & 5.68 & 1.8 & 2.6 \\
\hline 120 & 5.94 & 5.44 & 2.2 & 2.8 \\
\hline
\end{tabular}

It was found that in a sample with spelt flour, the acid accumulation process runs more intensively, probably due to the higher sugar content in spelt flour, which creates favourable conditions for yeasts [13].

As a next stage, it was determined how the wholemeal spelt flour affects the organoleptic and physical-and-chemical parameters of bread. Following the experimental laboratory baking, it was established that the bread samples with spelt flour have a more vibrant colour of the crust and a specific nutty aroma typical of spelt.

The change in the crumb acidity of the test samples correlated with the level of acidity during fermentation, so the crumb acidity in a bread sample with spelt flour increased by $7.14 \%$, compared with that of the control sample.

The inclusion of spelt flour into the bread formulation increases the moisture content of crumb in the study samples by $3.15 \%$. The specific volume of crumb reduced by $12.5 \%$ and the crumb porosity - by 5.1 $\%$.

Experimental data on the assessment of the effect of the dough-making method on the quality characteristics of bread containing $40 \%$ spelt flour are presented in Table 4, Figure 3.

Bread samples were made using the following methods: the sponge-and-dough method on a tight sponge, the straight dough method, and the accelerated method using the improving agent Magimix.

Table 4. Comparative analysis of physical and chemical parameters of bread quality in different dough-making methods.

\begin{tabular}{|l|c|c|c|}
\hline \multirow{2}{*}{ Parameter } & \multicolumn{3}{|c|}{ Dough-making method } \\
\cline { 2 - 4 } & $\begin{array}{c}\text { sponge-and- } \\
\text { dough } \\
\text { method }\end{array}$ & $\begin{array}{c}\text { straight } \\
\text { dough } \\
\text { method }\end{array}$ & $\begin{array}{c}\text { accelerated } \\
\text { method }\end{array}$ \\
\hline $\begin{array}{l}\text { Moisture } \\
\text { content of } \\
\text { crumb, \% }\end{array}$ & $44.35 \pm 4.6$ & $43.05 \pm 3.8$ & $40.90 \pm 3.4$ \\
\hline $\begin{array}{l}\text { Crumb acidity, } \\
\text { degrees }\end{array}$ & $3.4 \pm 0.2$ & $3.0 \pm 0.1$ & $2.8 \pm 0.1$ \\
\hline $\begin{array}{l}\text { Crumb } \\
\text { porosity, \% }\end{array}$ & $70.0 \pm 5.6$ & $68.0 \pm 4.9$ & $66.0 \pm 5.2$ \\
\hline $\begin{array}{l}\text { Shape } \\
\text { stability, } \\
\text { (H/D) }\end{array}$ & $0.44 \pm 0.05$ & $0.32 \pm 0.03$ & $0.33 \pm 0.04$ \\
\hline
\end{tabular}

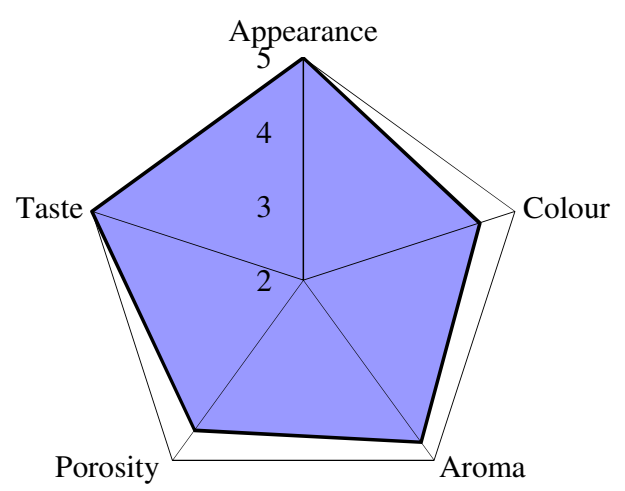

a - sponge-and-dough method 


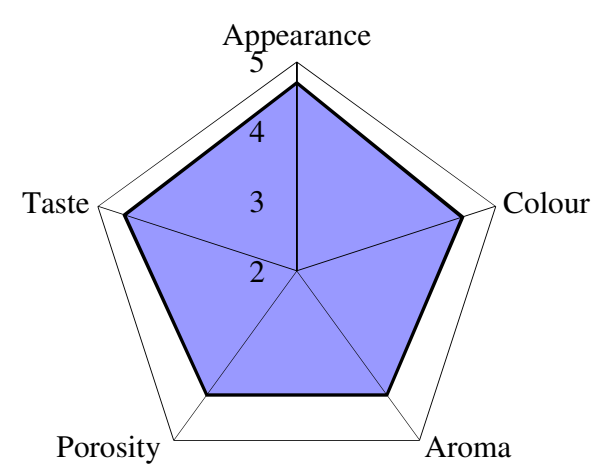

$\mathrm{b}-$ straight dough method

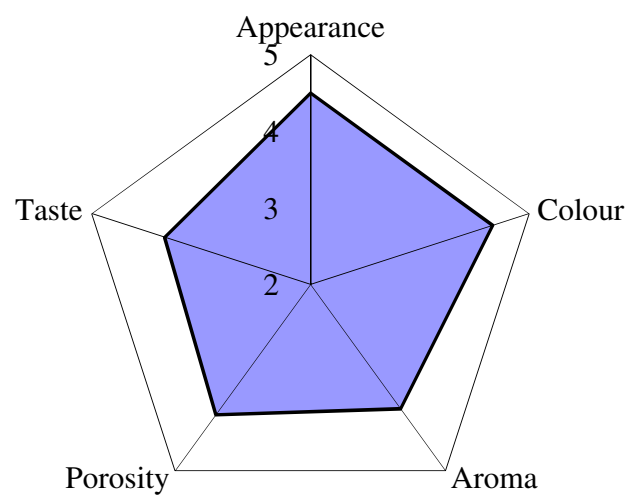

$\mathrm{b}$ - accelerated method

Fig. 3. Comparative analysis of organoleptic parameters of bread quality.

The best organoleptic and physical-and-chemical parameters were observed in the bread samples produced by the sponge-and-dough method, besides due to the high baking absorption of spelt flour, the flour should be added to a sourdough starter.

Based on the research results, the Khazri bread formulation was developed.

The assessment of the nutritional and energy value of Khazri bread showed that the use of spelt flour in the bread formulation increases proteins by $12.37 \%$ and dietary fibres - by $58.49 \%[14,15]$.

As the final stage of the study, we conducted a comprehensive assessment of the sanitary and hygienic status of the developed Khazri bread. In the test bread samples, the safety parameters prescribed by the requirements of the Technical Regulations of the Customs Union 021/2011 were determined.

The research results showed that the content of toxic elements, pesticides, mycotoxins and radionuclides in the Khazri bread is far below the permissible levels. Therefore, the wholemeal spelt bread is a high-quality product as far as the safety concerned.

\section{Conclusions}

Thus, in order to make the wheat bread, up to $40 \%$ of the wholemeal spelt flour can be used, which does not deteriorate its physical and chemical quality parameters and adds a specific taste and aroma to the product.

Due to the high content of proteins, dietary fibres, vitamins and minerals, this type of bread can be recommended as a functional product for mass consumption.

\section{References}

1. E. Escarnot, J.M. Jacquemin, R. Agneessens, M. Paquot, Biotechnol. Agron. Soc. Environ 16(2), 243-256 (2012)

2. G.V. Bonifácia, V. Galli, R. Francisci, V.Mair, V. Skrabanja, I. Kreft. Food Chem 68, 437-441 (2000)

3. M. Lacko-Bartošova,V. Čurná, L. LackoBartošova, Research Journal of Agricultural Science 47, 3-10 (2015)

4. M. Lacko - Bartošová, V. Čurná. Journal of Micro-biology Biotechnology and Food Science 4, 95-98 (2015)

5. T. Bojňanská, H. Frančáková. Rostl. Výr 48 (4), 141-147 (2002)

6. Z. Kohajdová, J. Karovičováżywność. Nauka. Technologia. Jakość 4 (53), 36 - 45 (2007)

7. S. Zanetti, M. Winzeler, C. Feullet, B. Keller, M. Messner. Plant Breeding 120, 13-19 (2001)

8. N. V. Sokol et al. IOP Conf. Ser.: Earth Environ. Sci. 640062016 (2021)

9. N. S. Sanzharovskaya, N. V. Sokol, O. P. Khrapko, K. S. O. Mamedov, N. N. Romanova, New technology 3, 60-65 (2018)

10. G. D. Meintjés. The use of HPLC for quality prediction of South African wheat cultivars. (Wyd. University of the Free State, Bloemfontein) (2004)

11. K. Stiegert, J. P. Blanc. J. Agric. Res. Econ 22 (1), 104-119 (2000)

12. T. J. Schober, I. Clarke, M. Kuhn. Cereal Chem 79 (3), 408-417 (2002)

13. Z. Petkova, S. Magdelana, S. Stankov, H. Fidan, M. Dzhivoderova, A. Pahopoulou, P. Merdzhanov, A. Koleva, S. Ercişli, A. Stoyanova. Food and Health 5(3), 160-167 (2019)

14. I.M. Skurikhin, V.A. Tutelyan Chemical composition of Russian food products. Handbook (M.: DeliPrint, 2002)

15. Norms of physiological needs in energy and food substances for various groups of the population of the Russian Federation. Methodical recommendation 2.3.1.2432-08 (M.: Federal Centre of the State Sanitary and Epidemiological Service of the Ministry of Health of the Russian Federation, 2008) 